\title{
Short-term Hypothermia Induces Beta-catenin-interacting Protein 1 Gene Expression in PC12 Cells
}

\author{
Kisang Kwon ${ }^{1, \$}$, Bo-Kyung Yoo ${ }^{4, \$}$, Eun Ryeong Lee ${ }^{1}$, Seung-Whan Kim ${ }^{2}$, \\ Kweon $\mathrm{Yu}^{3}$ and $\mathrm{O}-\mathrm{Yu} \mathrm{Kwon}^{4, \dagger}$ \\ ${ }^{l}$ Department of Biomedical Laboratory Science, College of Health \& Welfare, Kyungwoon University, \\ Gumi 39160, Korea \\ ${ }^{2}$ Department of Emergency Medicine, Chungnam National University Hospital, Taejon 35015, Korea \\ ${ }^{3}$ Korea Research Institute of Bioscience \& Biotechnology, Taejon 34141, Korea \\ ${ }^{4}$ Department of Anatomy, College of Medicine, Chungnam National University, Taejon 34134, Korea
}

The effects of hypothermic treatment $\left(32^{\circ} \mathrm{C}\right)$ on recovery from ischemia are controversial because the precise mechanisms of hypothermia remain unclear. We demonstrated previously that hypothermia induces beta-catenin-interacting protein 1 (CTNNBIP1) gene expression in vitro. In this study, we evaluated the effects of various hypothermic conditions, including lithium chloride treatment, on CTNNBIP1 gene expression. The results show that short-term hypothermic treatment resulted in relatively higher CTNNBIP1 gene expression than that of a longer treatment. These findings indicate that hypothermia controls CTNNBIP1 gene expression, which may provide clues to develop treatments to recover from and diagnose ischemia.

Key Words: Hypothermia, Beta-catenin-interacting protein 1 (CTNNBIP1), PC12 cells

Brain ischemia occurs when insufficient blood flows to the brain, leading to an alternative oxygen supply or cerebral hypoxia (Weinachter et al., 1990). Ischemia eventually leads to brain death due to the poor oxygen/ATP supply. Hypothermia is a strong neuroprotectant that reduces ischemic brain injury, but the detailed mechanisms of its protective effects are not entirely understood (Darwazeh and Yan, 2013). We showed previously that hypothermic treatment protects against central nervous system oxygen toxicity and ischemic brain injury, which are expected during emergency brain resuscitation of ischemic patients. We also previously demonstrated that hypothermia increases the expression of

\footnotetext{
* Received: August 10, 2015 / Revised: September 1, 2015

Accepted: September 18, 2015

$\S$ Authors contributed equally to this work.

${ }^{\dagger}$ Corresponding author: O-Yu Kwon. Department of Anatomy, College of Medicine, Chungnam National University, Taejon 34134, Korea.

Tel: +82-42-580-8206, Fax: +82-42-586-4800

e-mail: oykwon@cnu.ac.kr

(C) The Korean Society for Biomedical Laboratory Sciences. All rights reserved.
}

the beta-catenin-interacting protein 1 (CTNNBIP1) gene

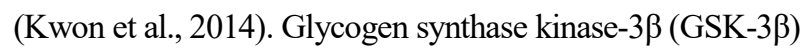
is an important cell survival signaling protein that activates hypoxia-inducible factor-1 and inhibits apoptosis ( $\mathrm{Li}$ et al., 2011). GSK-3 $\beta$ induces phosphorylation of $\beta$-catenin, which activates $\beta$-catenin-mediated gene expression, which is critical for $\beta$-catenin stability (Ray et al., 2015). $\beta$-catenin knockout results in apoptosis, whereas $\beta$-catenin overexpression prevents cell death (Holowacz et al., 2011). It has also been reported that hypothermic treatment decreases $\beta$-catenin degradation after ischemia (Zhang et al., 2008). CTNNBIP1 is recognized by leucine zipper tumor suppressor 2, which complexes with CTNNBIP1 and modulates the $\beta$-catenin signaling pathway (Stow, 2004). CTNNBIP1 negatively regulates $\mathrm{Wnt}$ signaling by inhibiting interactions with $\beta$-catenin (Cruciat et al., 2014). Our previous data showed that CTNNBIP1 gene expression is controlled by hypothermia, suggesting that heat acclimation treatment 
A

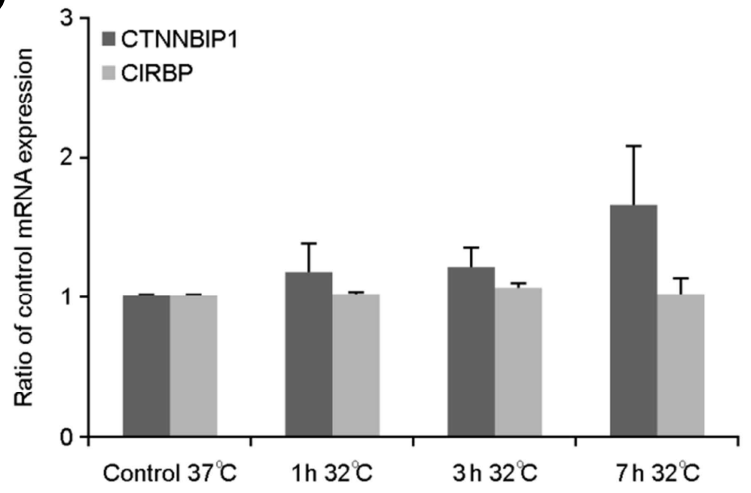

B

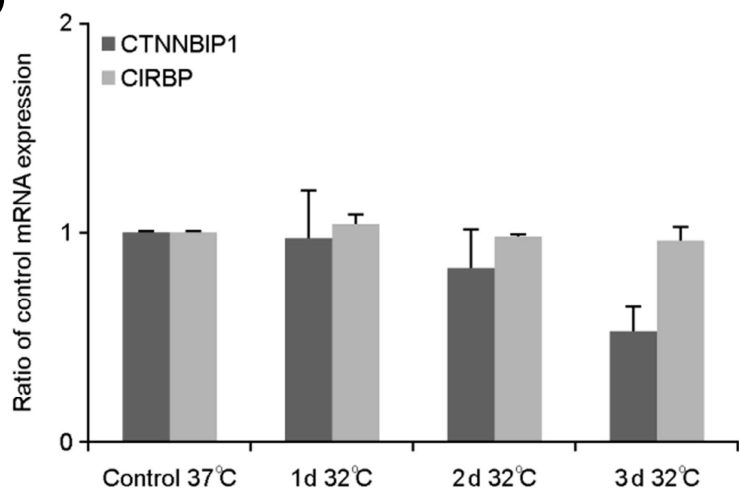

Fig. 1. Hypothermia regulates CTNNBIP1 mRNA expression. PC1 2 cells were exposed to hypothermia ( $\left.32^{\circ} \mathrm{C}\right)$ for different times. The hypothermic response was confirmed by increased CIRBP mRNA expression, which is a positive marker. CTNNBIP1, beta-catenin-interacting protein 1; CIRBP, cold-induced RNA-binding protein. The experiments were performed three times and the results represent the mean.

could be effective in ischemia (Kwon et al., 2014). In this study, we present the results of CTNNBIP1 gene expression under various hypothermic conditions including lithium chloride treatment in vitro.

PC12 cells were cultured on collagen-coated flasks in $85 \%$ RPMI 1640 supplemented with 25 mM HEPES buffer, 10\% heat-inactivated horse serum, 5\% heat-inactivated fetal bovine serum, $2 \mathrm{mM}$ L-glutamine, $1 \mathrm{mM}$ sodium pyruvate, $1 \mathrm{~g} / \mathrm{l} \mathrm{D}(+)$-glucose, $25 \mu \mathrm{g} / \mathrm{ml}$ streptomycin and $25 \mathrm{U} / \mathrm{ml}$ penicillin at $37^{\circ} \mathrm{C}$ in a $5 \% \mathrm{CO}_{2}$ atmosphere. The cells were incubated under control conditions $\left(37^{\circ} \mathrm{C}\right)$ or hypothermia $\left(32^{\circ} \mathrm{C}\right)$. The expression of the cold-induced RNA-binding protein (CIRBP) was used as a positive control (Al-Fageeh and Smales, 2009) in all experiments. Total RNA from cultured PC12 cells was extracted using an RNA isolation reagent (TRI-Reagent Ambion, Austin, TX, USA). A reverse transcription-polymerase chain reaction analysis was performed using the forward primer F (5'-ATGAACCGTGAGGGAGCAC-3') and R (5'-GATCTGGAAAACGCCATCAGC-3') for CTNNBIP1; F (5'-TCAGCTTCGACACCAATGAG-3') and R (5'-GTATCCTCGGGACCGGTTAT-3') for CIRBP. The conditions were: 30 cycles $\left[94^{\circ} \mathrm{C}\right.$ for $30 \mathrm{~s}$; $58^{\circ} \mathrm{C}$ for $30 \mathrm{~s}$; and $72^{\circ} \mathrm{C}$ for $1 \mathrm{~min}$ (final cycle of $10 \mathrm{~min}$ )] using Taq DNA polymerase.

CTNNBIP1 mRNA expression was increased gradually about two-fold in a time-dependent manner until $7 \mathrm{~h}$ compared to that of the control (Fig. 1A). However, expression decreased by about half during days $1 \sim 3$ of hypothermia exposure (Fig. 1B). These results show that hypothermia increased CTNNBIP1 gene expression only in the shortterm period ( $\leq 1$ day). We also tested the effect of 1,3 , and $5 \mathrm{~h}$ exposure to normal temperature after 2 days of hypothermic treatment on CTNNBIP1 gene expression (Fig. 2A). The resulting CTNNBIP1 gene expression was not repaired until its control. As shown in Fig. 1A, short-term hypothermic treatment increased CTNNBIP1 gene expression. To know, in this time, repeat treatments both $2 \mathrm{~h}$ normal temperature and $2 \mathrm{~h}$ hypothermia, which how to effect for the CTNNBIP1 gene expression (Fig. 2B). These results show that CTNNBIP1 gene expression increased about fourfold after two treatments. We also examined the effects of lithium chloride ( $\mathrm{LiCl}$ ), a well-known GSK-3 $\beta$ inhibitor, on CTNNBIP1 gene expression during hypothermic treatment (Fig. 3). LiCl reduces hypothermia through Tau hyperphosphorylation and enhances $\beta$-catenin protein expression (Meffre et al., 2015). A 2-day $\mathrm{LiCl}$ treatment $\left(37^{\circ} \mathrm{C}\right)$ resulted in downregulation of CTNNBIP1 gene expression. However, $\mathrm{LiCl}$ treatment under hypothermic conditions enhanced CTNNBIP1 gene expression, supporting the suggestion that hypothermia affects how $\mathrm{LiCl}$ interacts with unidentified intracellular thermal factors.

In summary, this is the first study to demonstrate that short-term hypothermic treatment upregulates CTNNBIP1 gene expression and that repeated-hypothermic treatment 
(A)

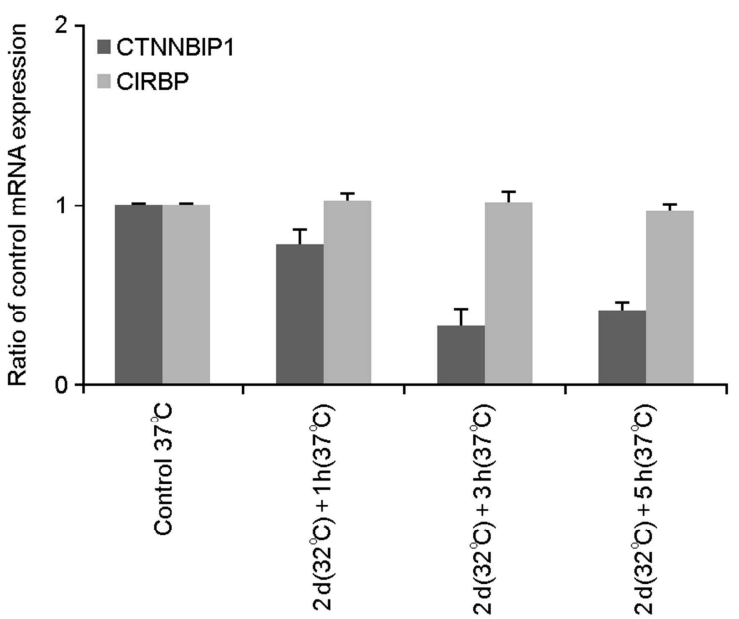

B

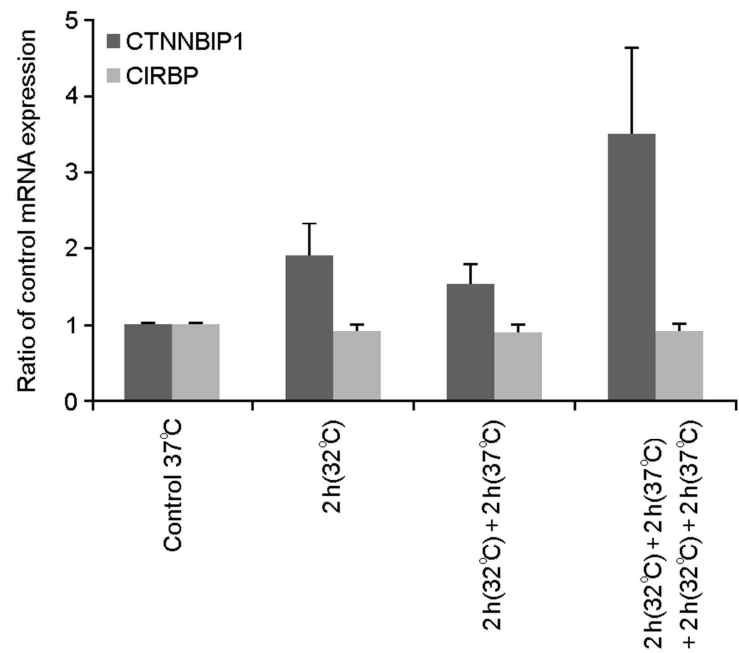

Fig. 2. Alternative hypothermia induces different CTNNBIP1 mRNA expression. After exposure to control conditions $\left(37^{\circ} \mathrm{C}\right), \mathrm{PC} 12$ cells were exposed to hypothermia $\left(32^{\circ} \mathrm{C}\right)$ at different times $(\mathrm{A})$ and temperatures $(\mathrm{B})$. CTNNBIP1, beta-catenin-interacting protein 1; CIRBP, cold-induced RNA-binding protein. The experiments were performed three times, and the results represent the mean.

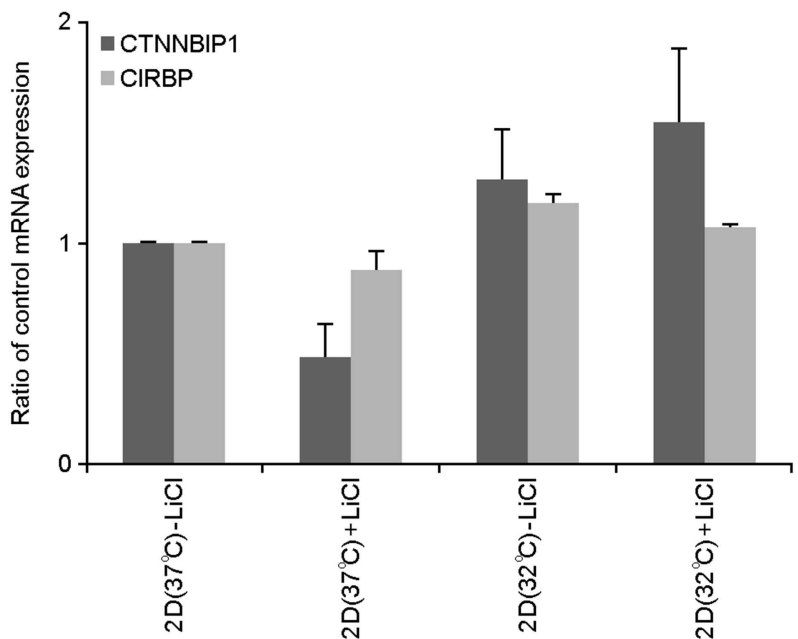

Fig. 3. The effect of lithium chloride on CTNNBIP1 mRNA expression. PC12 cells were incubated under control $\left(37^{\circ} \mathrm{C}\right)$ or hypothermic $\left(32^{\circ} \mathrm{C}\right)$ conditions with lithium chloride, respectively. CTNNBIP1, beta-catenin-interacting protein 1; CIRBP, cold-induced RNA-binding protein. The experiments were performed three times, and the results represent the mean.

induces relatively higher gene expression. $\mathrm{LiCl}$ upregulated CTNNBIP1 gene expression under hypothermic conditions. These in vitro findings indicate that hypothermia can be used to control CTNNBIP1 gene expression. An in vivo experi- ment must be conducted to verify these results and provide the possibility to develop brain ischemia recovery treatment and diagnostic method.

\section{Acknowledgements}

This study was supported by a research fund from Chungnam National University.

\section{Conflict of interest}

The authors declare that there is no conflict of interests regarding the publication of this article.

\section{REFERENCES}

Cruciat CM. Casein kinase 1 and Wnt/ $\beta$-catenin signaling. Curr Opin Cell Biol. 2014. 31: 46-55.

Darwazeh R, Yan Y. Mild hypothermia as a treatment for central nervous system injuries: Positive or negative effects. Neural Regen Res. 2013. 8: 2677-2686.

Holowacz T, Huelsken J, Dufort D, van der Kooy D. Neural stem cells are increased after loss of $\beta$-catenin, but neural pro genitors undergo cell death. Eur J Neurosci. 2011. 33: 1366 -1375 .

Kwon K, Kim SW, Yu K, Kwon OY. Expression of beta-catenin- 
interacting Protein 1 (CTNNBIP1) Gene is increased under hypothermia but decreased under additional ischemia conditions. Biomed Sci Lett. 2014. 20: 168-172.

Li Q, Michaud M, Canosa S, Kuo A, Madri JA. GSK-3ß: a signaling pathway node modulating neural stem cell and endothelial cell interactions. Angiogenesis. 2011. 14: 173-185.

Meffre D, Massaad C, Grenier J. Lithium chloride stimulates PLP and MBP expression in oligodendrocytes via $\mathrm{Wnt} / \beta$-catenin and Akt/CREB pathways. Neuroscience. 2015. 284: 962-971.

Ray M, Rai N, Jana K, Ghatak S, Basu A, Mustafi SB, Raha S. Beta catenin is degraded by both caspase- 3 and proteasomal activity during resveratrol-induced apoptosis in HeLa cells in a GSK3 $\beta$-independent manner. Indian J Biochem Biophys. 2015. 52: 7-13

Stow JL. ICAT is a multipotent inhibitor of beta-catenin. Focus on "role for ICAT in beta-catenin-dependent nuclear signaling and cadherin functions". Am J Physiol Cell Physiol. 2004. 286: C745-746.

Weinachter SN, Blavet N, O'Donnell RA, MacKenzie ET, Rapin JR. Models of hypoxia and cerebral ischemia. Pharmacopsychiatry. 1990. Suppl 2: 94-97.

Zhang H, Ren C, Gao X, Takahashi T, Sapolsky RM, Steinberg GK, Zhao H. Hypothermia blocks beta-catenin degradation after focal ischemia in rats. Brain Res. 2008. 1198: 182-187. 